\title{
ANALYSIS OF DETERMINATION THE NUMBER PERSONNEL BASED ON WORKLOAD ACCORDING TO JOB DESCRIPTION (STUDY CASE IN ACCOUNTING INSTITUTIONS)
}

\author{
Ahmadi $^{1}$, Wahyu Endriyanto ${ }^{2}$, Benny Sukandari ${ }^{3}$, Agus Makhrowi ${ }^{4}$ \\ 1,2,4 Indonesian Naval Technology College, STTAL. Surabaya Indonesia \\ 3Indonesia Naval Staff and Command College, Seskoal Jakarta
}

\begin{abstract}
The workload is highly related to efficient and effective human resource utilization in an organization to achieve organizational objectives, vision, and mission. Various methods are used to optimize the number of personnel in an organization so that each task can be completed quickly and precisely. Accounting Institutions are inseparable from problems regarding the lack of workload with the number of personnel working on it. The change of the Policy gives an impact on the change of Job Description and List of Personnel Arrangements of the organization. To overcome these issues, workload measurement, analysis can be used to determine the optimal amount of personnel required in their working units. This study uses a mental workload measurement so called NASA-TLX and physical workload measurement According to the applicable workload regulation that is in accordance with the Administrative Direction of Workload Analysis. Both methods are then carried out to be compared to each other. The results showed that the physical workload is required in the completion of tasks in each work unit. In addition, the determination of the optimal number of personnel using physical workload or appropriate tasks per task position based Job Description is performed. As a result, it is known that there is an excessive workload in the Sub Service Budget Cost work units with personal shortcomings. On the other hand, there is an excessive personnel number in Administrative Work, Sub Department of Finance Administration and Sub Department Financial Control. The overall conclusion of this study is a need for personnel reduction in a List of Personnel Arrangements currently known as Accounting Institutions to be 39 personnel instead of the existing 48 personnel.
\end{abstract}

Keywords: Workload, NASA-TLX (Task Load Index), assignments Per Task title, Number of Optimal personnel.

\section{INTRODUCTION.}

The East Fleet financial service is an organizational unit in the financial sector of the Navy's eastern fleet in the eastern part of Indonesia, which has the duty and authority to carry out the services and administration of financial reports to the Navy's Finance Department at the Indonesian Navy's Finance headquarters. Includes budgeting, financing, accounting, controlling, reporting and financial accountability in the environmental field from the budget of the user organization served. In carrying out the functions and duties, Head of Eastern Fleet Financial Services, assisted by US executives in each unit / work section, namely the Officers, among others, Head of Budget and Finance Sub Department, Head of Sub Department of Accounting, Head of Sub Department of Financial Administration and Head of Sub Department of Financial Control. In general, each division/work unit acting has assigned tasks and responsibilities in accordance with their respective job descriptions and has been adjusted to the list of personnel arrangements in the organizational structure that has been set. 
While the List of Personnel Arrangements is valid and has been updated after bureaucratic reforms often change because the change of leadership/command leader results in policy changes. Furthermore, there is still no reference in determining the right amount of optimal personnel workload that it faces. The list of Personnel Arrangements in each office/work unit division is still lacking or incorrectly referring to the actual needs of the organization, in the sense that they do not meet the tasks and functions of the mental workload and organization in the environment towards the right organization (the right size). The right size measure is intended, that is the right goal, the right function, the right composition and the right structure to achieve an effective and efficient organization.

Along with the existence of the policy changes occur, then each part required to always adjust to the new rules, it does affect the number of appropriate personnel arrangements of the Personnel List. Problems that often occur in a section/work unit that is a build up of personnel in one unit to another without a clear job and lack of personnel in other units. Because of the existence of a clear adjustment against the design calculation in determining the appropriate amount of optimal personnel workload in each section/unit of work and determine the value terms (job value) and class position (job class) each term per section/unit of work based on the analysis of the position, so this is a real example of these problems. Refers to the type of work of each of its parts, each part in order to complete the required tasks and obligations timely and professional. Therefore, the workload incurred in each part differs and adjustments the expected number of personnel.

The workload is an important factor for determining HRM policies in the system, for example, the planning needs of employees. Mental workload terminology refers to the time parameter. This means that the percentage of working time effective use by employees (Niebel, 2002). Workload not only calculates the time spent in productive work, but includes calculating the human aspects, such as fatigue, personal needs, and looseness factor (Barnes, 1980). It is also associated with the workload to be borne within a work unit/section within the organization. The workload is happening comes from the work that is routine, periodic/recurring or situational and incidental executed by every section of the work unit in his work set out in the Job Description of each position each section of the work unit. In creating the effectiveness, efficiency and productivity performance in the areas of human resources it can be done in various ways, including analysis of rights to the activities and workload incurred to determine the number of personnel needed in an organization, especially the east fleet financial service

From this problem, it will be examined more deeply, with the aim of knowing the mental workload and physical workload of each part/work unit of personnel so as to create equal workload. Workload identification will be divided into physical workload by using the calculation method of task workload analysis per position and mental workload using the NASA-TLX method. Then the two workloads will be compared. While the calculation for obtaining the optimal number of personnel uses the results of calculating the physical workload, which is according to the applicable rules.

This paper has any literature to support the research about it, for example, paper with title Workload Analysis for Planning Needs of Employees in The Corporate Administration Unit PT. Timah (Persero) Tbk (Gustomo, 2013). It's 
used a work sampling method as research to measure the workload. Fuzzy-TLX: using fuzzy integrals for evaluating human mental workload with NASA-Task Load index in laboratory and field studies (Marc, 2013). Evaluation of Mental Ward's Workload among ICU Nurses (Mohsen, 2015). This research is using the NASA-TLX method for assessment of workload for identifying performance obstacles associated with ICU nursing. NASA Task Load Index Scale to Evaluate the Cognitive mental Workload during Cardiac

Anesthesia Based Simulation Scenarios (Bhandary, 2016). Evaluation of Rating Scale Mental Effort (RSME) effectiveness of the mental workload assessment in nurses. This research in the assessment of mental workload on 75 nurses by using the NASA-TLX and RSME (Ghanbary, n.d.). Using Outputs of the NASA-TLX for Building a Mental Workload Expert System. This study chose NASA-TLX to use measurement techniques of the workload because it is a convenient measure for experiment groups (Seker, 2014). Maximizing Efficiency and Reducing Robotic Surgery Costs Using the NASA Task Load Index. This research is using NASA-TLX to demonstrate that high physical effort, and temporal demands for personnel assisting with and performing robotic surgery (Carrie, 2017). Discriminating the workload relative level of data envelopment analysis. In this model chooses the favorable set of weights under constraints for an employee (Shiow-Yun Chang, 2006). Assessment of Workload Using NASA Task Load Index in Paranesthesia Nursing. The NASA Task Load Index is a multifaceted tool for evaluating subjective workload (Gloria, 2008). Comparison of the perceived mental burden on the effectiveness of the new index using the Multiple resource questionnaire (Ben, 2014).

The benefits of this research are expected to be the basis of calculations to determine the optimal number of personnel needs in the east fleet financial institutions and for equalizing the workload in each part of the unit.

\section{MATERIALS/METHODOLOGY}

\subsection{Workload Analysis}

A workload is a number of job targets or outcome targets that must be achieved in one set of time, this is stated in Government Institutions Decree in 2004. Workload Analysis is a technique to determine the number and type of work of an organizational unit that is carried out systematically using job analysis techniques by paying attention to other management techniques.

According to (Chang and Chen, 2006), the measurement of mental workload can be done in two ways: objective work

measurement and subjective work measurement. Objective work measurement can be done with several body members, including heart rate, blinking of the eyes and muscle tension. Subjective measurement is the most widely used measurement technique because it has a high level of validity and is directly compared to other measurements.

\subsection{NASA-TLX calculations}

The method NASA-TLX (Task Load Index) is a subjective method that is often used in the measurement of mental workload on individuals in various fields of endeavor. On the methods of the NASA-TLX, there are 6 components that will be measured for each individual, namely the mental needs, physical needs, the needs of the time, the level of frustration, the performance and the last one is the level of effort. On the component needs mental, physical needs, the needs of the time and the level of frustration, the scale used is 
low to high. While performance measurement used to scale well to bad (Young and Zavelina, 2008).

Table 1. Description of the dimensions of NASA-

TLX

\begin{tabular}{|l|l|}
\hline \multicolumn{1}{|c|}{ Dimensions } & Scale \\
\hline $\begin{array}{l}\text { Mental Demand (MD) } \\
\text { How much demand for mental and perceptual } \\
\text { activities is needed in your work (example: } \\
\text { thinking, deciding, counting, remembering, } \\
\text { seeing and searching). Is the job easy or difficult, } \\
\text { simple or complex, loose or tight? }\end{array}$ & Low - High \\
\hline $\begin{array}{l}\text { Physical Demand (PD) } \\
\text { How much physical activity is needed in your } \\
\text { work (example: pushing, pulling, rotating, } \\
\text { controlling, running, etc.). Is the job easy or } \\
\text { difficult, slow or fast, calm or hurry? }\end{array}$ & Low - High \\
\hline $\begin{array}{l}\text { Time Demand (TD) } \\
\text { How much time pressure do you feel during work } \\
\text { or elements of work taking place? Is the job slow } \\
\text { and relaxed, or fast and tiring? }\end{array}$ & Low - High \\
\hline $\begin{array}{l}\text { Performance (P) } \\
\text { How big is your success in achieving your work } \\
\text { target? How satisfied are you with your } \\
\text { performance in achieving these targets? }\end{array}$ & Low - High \\
\hline $\begin{array}{l}\text { Effort (EF) } \\
\text { How much effort do you spend mentally and } \\
\text { physically needed to reach your level of } \\
\text { performance? }\end{array}$ & Low - High \\
\hline $\begin{array}{l}\text { Frustation (FR) } \\
\text { How big is insecurity, despair, offense, stress, } \\
\text { and disturbance compared to feeling safe, } \\
\text { satisfied, suitable, comfortable, and self- } \\
\text { satisfaction that is felt during the work? }\end{array}$ & Low - High \\
\hline
\end{tabular}

The next step is processing data until the acquisition of workload (Hart and Staveland, 1988) and the steps are as follows:

Calculate the product value

Product $=$ Rating $\times$ Weight Factor

Calculate the value of Weighted Workload (WWL)

Calculate the average of WWL

Average $\mathrm{WWL}=\mathrm{WWL} / 15$

This method is used to determine the mental load of personnel. The determination of this mental burden is based on the WWL average value of each personnel. While the category of workload that can indicate as follows:
Table 2. NASA-TLX Workload Category

\begin{tabular}{|c|c|c|}
\hline No. & WWL Average Value Range & Workload Category \\
\hline 1 & $0-9$ & Low \\
\hline 2 & $10-29$ & Medium \\
\hline 3 & $30-49$ & High \\
\hline 4 & $50-79$ & Rather High \\
\hline 5 & $80-100$ & Very High \\
\hline
\end{tabular}

\subsection{The calculation of workload with the} task approach of each job assignment

Calculation of workload assignments each task approach position are three aspects to consider, among other things:

1. The Workload.

2. Standard Traffic average.

3. Working Time.

The calculation of the amount of the required personnel, sought after as in the formula:

Number of Personnel $=\frac{\sum \text { Time end of the job }}{\sum \text { Effective time job }}$

\subsection{Methodology of Research}

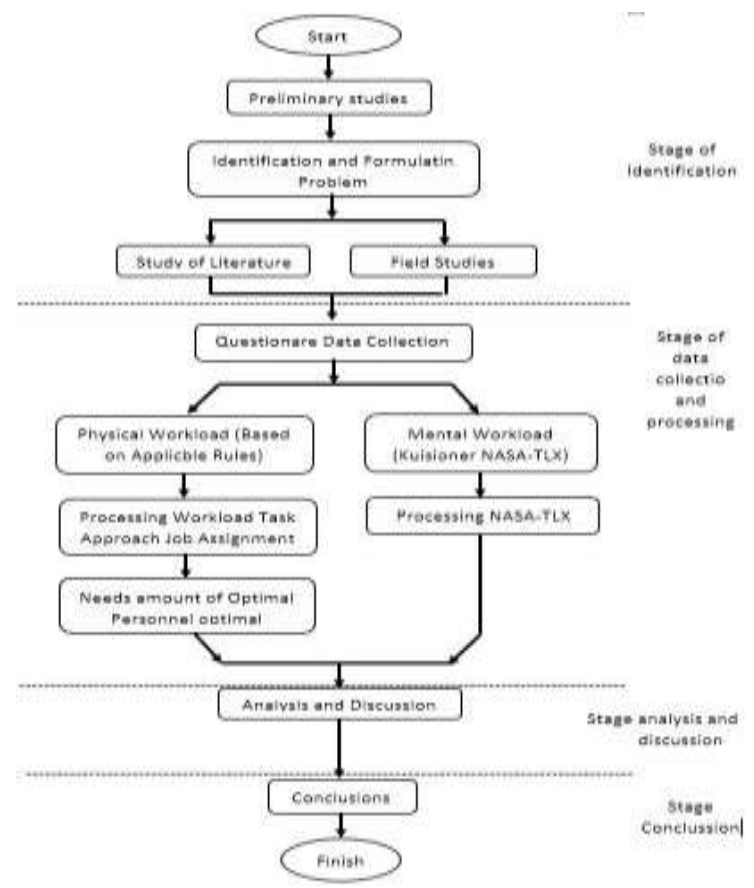

Fig.1 Research Flow Diagram 
This stage begins with an introduction, discusses the problem, studies the literature and the field, makes the NASA-TLX questionnaire and the Completion Time Task according to the job description, discusses and collects the questionnaire from the respondent, data processing, data analysis, conclusions, and suggestions.

Data sources were obtained from 13 respondents who were appointed as leaders of each work unit/section.

After all, the questionnaire data has been collected, then the next calculation of the respondents' assessment results. In the NASA-TLX calculation, the number of ranks is multiplied by the number of weighting results, namely WWL (Weighted Workload) and from the multiplication of ranks and the weight of each indicator, then divided by Divided Constant, 15 is the number of comparisons and then the Weighted Workload is obtained (AVG WWL) or Average Workload. This is shown in Table 5.

Meanwhile, to calculate the physical workload (Approach to the burden of each position/section), the Settlement Time is sought (Table 6).

From the results obtained in this study that is compared between the mental and physical burden on each section, the number of personnel with the optimal approach of physical workloads or appropriate task per task Office based on Job Description and evaluation of the value of them as well as the structural position of each class section of the Office in the Eastern Fleet Finance Offices.
This method of measurement, implemented through three stages, namely to calculate the value of the product with multiple rating with weights, calculating the Weighted Workload (WWL) and calculate the average of WWL.

Most Influential Descriptors Position is in table 3.

Table 3. Influential Descriptors

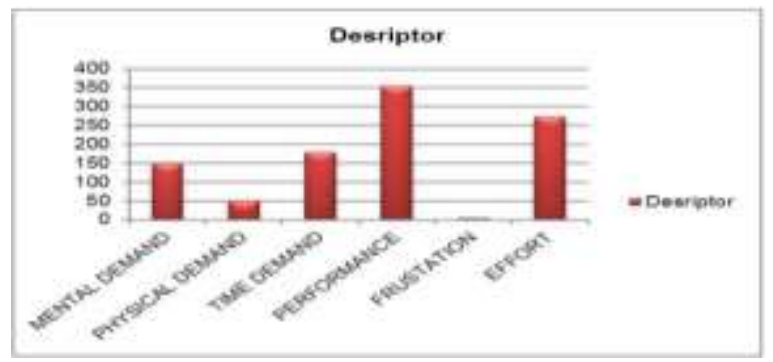

Table 4. The Average Workload of The Auxiliary Elements of The Leadership

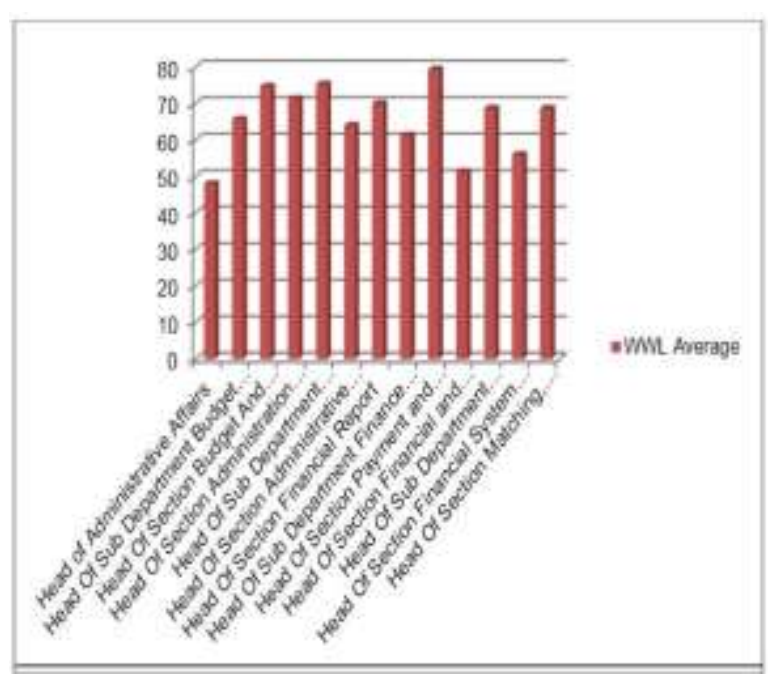

The total value of the processing results, recaps WWL and WWL average can be seen in the following table: 
Table 5. The Total Value of The WWL Recap and The Average Value of WWL

\begin{tabular}{|c|c|c|c|c|}
\hline Ne. & Posingen & $\begin{array}{l}\text { Joinl } \\
\text { Yakie: } \\
\text { Wow }\end{array}$ & $\begin{array}{l}\text { Awerage Value } \\
\text { What }\end{array}$ & $\begin{array}{l}\text { Gaingony } \\
\text { good wo }\end{array}$ \\
\hline 1 & $\begin{array}{l}\text { Fead of } \\
\text { Administrotive Affaiss }\end{array}$ & 720 & 4002 & Mosurs \\
\hline 2 & $\begin{array}{l}\text { Mead or Sub } \\
\text { Dopartmenen Budget } \\
\text { And Finance }\end{array}$ & 985 & 6567 & $\mathrm{Hegh}$ \\
\hline 3 & $\begin{array}{l}\text { Head or Sketion } \\
\text { Budget Ans Fiemora }\end{array}$ & 1120 & 74.67 & $\mathrm{H}$-gh \\
\hline 4. & $\begin{array}{l}\text { Head or Secton } \\
\text { Administration } \\
\text { Budret And Flasose }\end{array}$ & 1000 & 71.31 & $\mathrm{High}$ \\
\hline 5 & $\begin{array}{l}\text { Head of Sub } \\
\text { Deppartinent } \\
\text { Accosanting }\end{array}$ & 1130 & 75.31 & $\mathrm{High}$ \\
\hline 6 & $\begin{array}{l}\text { Hewd or Section } \\
\text { Administrative } \\
\text { Accolnting }\end{array}$ & 950. & 64.02 & High \\
\hline 7 & 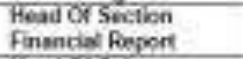 & 1250 & 70.00 & $\mathrm{High}$ \\
\hline B & $\begin{array}{l}\text { Hesd or Sub } \\
\text { Department Finance } \\
\text { Administrosion }\end{array}$ & 920 & 61.31 & $\mathrm{Hagh}$ \\
\hline 9 & $\begin{array}{l}\text { Hesd of Section } \\
\text { Payanear and Incorme }\end{array}$ & 179 & 7835 & $\mathrm{Hahh}$ \\
\hline 10 & $\begin{array}{l}\text { Hesd Of Section } \\
\text { Financidiand } \\
\text { Peraomel Data }\end{array}$ & 770 & 51.33 & $\mathrm{High}$ \\
\hline 15 & $\begin{array}{l}\text { Hood of Sub } \\
\text { Depantmant Financial } \\
\text { Conerol }\end{array}$ & $\omega \infty 0$ & 60.67 & $\mathrm{Mgh}$ \\
\hline 12 & $\begin{array}{l}\text { Hesd of Section } \\
\text { Finamcial Sysiem } \\
\text { Cnecting }\end{array}$ & 840 & 56.00 & Migh \\
\hline 13 & $\begin{array}{l}\text { Hwad of Section } \\
\text { Matchingi. Peenarch } \\
\text { Fnence }\end{array}$ & 1080 & 69.67 & High \\
\hline
\end{tabular}

Mental workload calculation shows the results of that on the structural position of Head of Sub Department Budget and Finance, Head of Sub Department Accounting, Head of Sub Department of Finance Administration and Head of Sub Department Financial Control have the mental workload is high, that is above 50 . While at the Head of Administrative Affairs has only a moderate workload, with values above 30 . These values indicate that in conducting its work, the influential mental workload as well. And on average workload, show that officials of the structural descriptors the most influential are $P$, that $P$ is a performance work from every Office of the Division. Thus, it can be concluded that the success of the very influential work on mental workload faced by each Office Division/work unit.

Whereas the descriptors FR or frustrating not so influential in doing the work. It is closely related to how hard physical and mental effort that should be issued by the personnel Division/work unit while doing the work, because at the start of mapping personnel have already adapted to the profession and expertise each so There are no constraints in terms of frustrating and preferred is mental and physical in completing each task. The presence of the most influential of these descriptors, it is possible due to the nature of the work, the personnel charged at every position each section more accentuated on the success or the success rate of its work.

After that, physical workload processing (according to the Administrative Direction of Workload Analysis). Processing Physical workload in advance must be made to the collection of data regarding the Labor Day holiday, active personnel, working hours imposed in Accounting Institutions and data activity every time personnel. Next to the data processed to obtain the effective working time, working hours and time effective completion of the tasks that become the burden of any personnel.

Table 6. The Results of The Calculation with A Recap of the Load Approaches Each Position/Parts

\begin{tabular}{|c|c|c|c|}
\hline No & Position & $\begin{array}{l}\text { Total Task } \\
\text { Completion } \\
\text { Time } \\
\text { (Min / Day) }\end{array}$ & $\begin{array}{l}\text { Number of } \\
\text { Personnel } \\
\text { that Shiculd } \\
\text { Be Required } \\
\text { (Ptople) }\end{array}$ \\
\hline 1 & Head of Administrative Affairs & 930 & 2.734 \\
\hline 2 & $\begin{array}{l}\text { Head of Sub Department Budget And } \\
\text { Finance }\end{array}$ & 1860 & 5.467 \\
\hline 3 & Head of Section Budget And Finance & 1660 & 4.656 \\
\hline 4 & $\begin{array}{l}\text { Head Of Section Administration Budget } \\
\text { And Finance }\end{array}$ & 1140 & 3.351 \\
\hline 5 & Head Of Sub Department Accounting & 1740 & 5.115 \\
\hline 6 & $\begin{array}{l}\text { Head Of Section Administrative } \\
\text { Accounting }\end{array}$ & 1020 & 2.998 \\
\hline 7 & Head Of Section Financial Report & 1020 & 2.998 \\
\hline 8 & $\begin{array}{l}\text { Head Of Sub Department Finance } \\
\text { Administration }\end{array}$ & 540 & 1.587 \\
\hline 9 & Head Of Section Payment and Income & 420 & 1.235 \\
\hline 10 & $\begin{array}{l}\text { Head Of Section Financial and Personnel } \\
\text { Data }\end{array}$ & 450 & 1.323 \\
\hline 11 & $\begin{array}{l}\text { Head Of Sub Department Financial } \\
\text { Control }\end{array}$ & 1320 & 2.880 \\
\hline 12 & $\begin{array}{l}\text { Head Of Section Financial System } \\
\text { Coaching }\end{array}$ & 720 & 2.116 \\
\hline 13 & $\begin{array}{l}\text { Head of Section Matching, Research } \\
\text { Finance }\end{array}$ & 840 & 2.469 \\
\hline
\end{tabular}


On the calculation approach of load assignment per post of seeing results that at the post of Head of Sub Department Budget and Finance have total time completion of tasks that is 1860. This result is very far from the Head of Section Payment and Income that only has a total of 420 task completion times.

This can be caused by several factors, including the details of tasks not thorough of the holder of the Office or indeed the existence of the uneven allocation of tasks for both the Office.

However, if the return on the results of observations made, for the task of Head of Sub Department Budget and Finance should be made the adjustment of the number of personnel required. A considerable result also was found on the post of Head of Sub Department Accounting for a total time of 1740 .

However, due to the position of Head of Sub Department of Budget and Finance and Head of Sub Department Accounting only filled each 1 person, then to reduce the burden of Head of Sub Department of Budget and Finance and Head of Sub Department Accounting This can be done by means of the addition of a member as his Assistant or do adjustments back the number of personnel needed by the workload of their structures.

Next will be made Comparison of the Results of Measurement of NASA-TLX Mental Load Method with Physical Workload.
Table 7. Comparative analysis of the results of the Mental Workload and Physical Workload.

\begin{tabular}{|c|c|c|c|c|c|}
\hline No. & Head of Unit/ Part & $\begin{array}{l}\text { Mental } \\
\text { Work Load } \\
\text { (NASA- } \\
\text { TLX) score }\end{array}$ & Category & $\begin{array}{l}\text { Physical } \\
\text { Work Load } \\
\text { Score }\end{array}$ & Category \\
\hline 1 & $\begin{array}{c}\text { Head of } \\
\text { Administrative } \\
\text { Affairs }\end{array}$ & 2 & Medium & 3 & High \\
\hline 2 & $\begin{array}{l}\text { Head Of Sub } \\
\text { Department Budget } \\
\text { And Finance }\end{array}$ & 3 & High & 4 & Very High \\
\hline 3 & $\begin{array}{l}\text { Head Of Section } \\
\text { Budget And } \\
\text { Finance }\end{array}$ & 3 & High & 4 & Very High \\
\hline 4 & $\begin{array}{l}\text { Head Of Section } \\
\text { Administration } \\
\text { Budget And } \\
\text { Finance }\end{array}$ & 3 & High & 3 & High \\
\hline 5 & $\begin{array}{l}\text { Head Of Sub } \\
\text { Department } \\
\text { Accounting }\end{array}$ & 3 & High & 4 & Very High \\
\hline 6 & $\begin{array}{l}\text { Head Of Section } \\
\text { Administrative } \\
\text { Accounting }\end{array}$ & 3 & High & 3 & High \\
\hline 7 & $\begin{array}{l}\text { Head Of Section } \\
\text { Financial Report }\end{array}$ & 3 & High & 3 & High \\
\hline 8 & $\begin{array}{l}\text { Head Of Sub } \\
\text { Department } \\
\text { Finance } \\
\text { Administration }\end{array}$ & 3 & High & 2 & Medium \\
\hline 9 & $\begin{array}{l}\text { Head Of Section } \\
\text { Payment and } \\
\text { Income }\end{array}$ & 3 & High & 1 & Low \\
\hline 10 & $\begin{array}{c}\text { Head Of Section } \\
\text { Financial and } \\
\text { Personnel Data }\end{array}$ & 3 & High & 2 & Medium \\
\hline 11 & $\begin{array}{c}\text { Head of Sub } \\
\text { Department } \\
\text { Financial Control }\end{array}$ & 3 & High & 3 & High \\
\hline 12 & $\begin{array}{l}\text { Head Of Section } \\
\text { Financial System } \\
\text { Coaching }\end{array}$ & 3 & High & 2 & Medium \\
\hline 13 & $\begin{array}{l}\text { Head of Section } \\
\text { Matching, } \\
\text { Research Finance }\end{array}$ & 3 & High & 2 & Medium \\
\hline
\end{tabular}

On the comparison of the results of the calculation of workload is based on the value of the grant of the workload of each category and the value of the workload that is between mental workloads in accordance with NASA-TLX workload and physical workload corresponding institution the Ministry of State Apparatus/Ministry of Defense. In a comparison of these results, the physical workload is sorted according to the categories that have been made in the mental workload calculation with the NASA-TLX, which is also made in 4 categories among other categories of low, medium, high and very high. 
This award is made based on the range of physical workload that is by looking for the value of the minimum and maximum of the total time completion of tasks each position.

From the results of these comparisons can be obtained that the mental workload of the Office of the Head of Administrative Affairs obtains load value or category 2 or medium and the physical workload with load value 2 or higher category. This means the mental burden is not so influential on task completion time and workmanship, as well as physical needs not so much, require personnel. Because of the appropriate task completion time calculation results, with minimal personnel capable of working on its task very well. On the mental workload post of Head of Sub Department Budget and Finance has a value of 3 with a load of high category and physical workload with load value 4 categories are very high. Therefore, it can be concluded that the physical workload on the Head of Sub Department Budget and Finance larger than her mental workload, meaning mental pressures facing lower than physical because when working on any his job requires a considerable task completion time. So the necessary personnel power pretty much anyway. The case that occurred in the Office of the Head of the Budget and Finance Section and the Head of Sub Department Accounting. Overall comparisons of each such term, high mental workload is not reference was made to add personnel.

The Optimal Number Personnel refers to the results of the calculations in table 6 , namely rounding up on the results Number of Personnel Needed. And the following results are obtained:
Table 8. The Optimal Number of Personnel Calculation Results

\begin{tabular}{|c|c|c|c|c|c|c|}
\hline ib & Hererotillint & 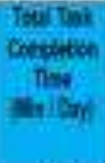 & 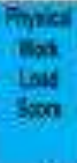 & 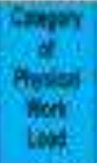 & 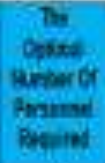 & irlongats \\
\hline \multirow[t]{2}{*}{1} & \multirow{2}{*}{$\begin{array}{l}\text { Hed of haninstative } \\
\text { Mtars }\end{array}$} & \multirow[t]{2}{*}{30} & \multirow[t]{2}{*}{ J } & \multirow[t]{2}{*}{ High } & \multirow[t]{2}{*}{ J } & Therd \\
\hline & & & & & & 2507 \\
\hline \multirow[t]{2}{*}{2} & \multirow{2}{*}{$\begin{array}{c}\text { Hod 015d } \\
\text { Depotraci Bodak Aod } \\
\text { Finavoe }\end{array}$} & \multirow[t]{2}{*}{1850} & \multirow[t]{2}{*}{4} & $\mathrm{~mm}$ & \multirow[t]{2}{*}{5} & IHasd \\
\hline & & & & High & & 4507 \\
\hline \multirow[t]{2}{*}{2} & \multirow{2}{*}{$\begin{array}{l}\text { Head of Secter Budget } \\
\text { Kend Fisence }\end{array}$} & \multirow[t]{2}{*}{1650} & \multirow[t]{2}{*}{4} & $\mathrm{~m}$ & \multirow[t]{2}{*}{5} & Ithas \\
\hline & & & & Hogh & & 48at \\
\hline \multirow[t]{2}{*}{4} & \multirow{2}{*}{ 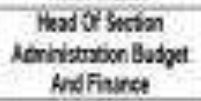 } & \multirow[t]{2}{*}{1180} & \multirow[t]{2}{*}{ d } & \multirow[t]{2}{*}{ hob } & \multirow[t]{2}{*}{$J$} & 5 head \\
\hline & & & & & & $\frac{1}{25 a t}$ \\
\hline \multirow[t]{2}{*}{8} & \multirow{2}{*}{$\begin{array}{c}\text { Heas or } 36 \\
\text { Deperment Acosintirs }\end{array}$} & \multirow[t]{2}{*}{130} & \multirow[t]{2}{*}{4} & $V_{B S}$ & \multirow[t]{2}{*}{5} & I Head \\
\hline & & & & High & & 682t \\
\hline \multirow[t]{2}{*}{1} & \multirow{2}{*}{ 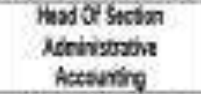 } & \multirow[t]{2}{*}{1620} & \multirow[t]{2}{*}{2} & \multirow[t]{2}{*}{ High } & \multirow[t]{2}{*}{3} & Shesd \\
\hline & & & & & & 2524 \\
\hline \multirow[t]{2}{*}{$T$} & Hesdorsucion & 1000 & 3 & High & 5 & I Head \\
\hline & Fitsoncil Arout & & & & & 3527 \\
\hline 8 & Hed orses & 58 & 2 & Vediun & 2 & f Head \\
\hline & 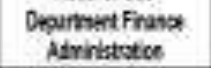 & & & & & 1501 \\
\hline 5 & Hasd or Buclisn & 420 & t & Lax & t & Ithas \\
\hline & Payrent sne heent & & & & & ? \\
\hline 9 & Head Q SHelsi & 48 & 2 & Vodint & 1 & SHad \\
\hline & 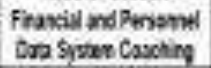 & & & & & . \\
\hline it & Hado:sD & 1320 & 3 & Hgh & i & Ithad \\
\hline & $\begin{array}{c}\text { Depatresel Fiencelal } \\
\text { Cortol }\end{array}$ & & & & & 3507 \\
\hline
\end{tabular}

The next step is processing data until the acquisition of the workload.

Determination of the optimal number of calculation results of personnel can be seen in the previous chapter, which is listed according to the result is as follows, namely, Head of Administrative Affairs 3 person personnel, Sub Department Budget and Finance personnel, 13 people Sub Department Accounting 11 personnel, Sub Department Finance Administration personnel and four Sub Department Financial Control 8 personnel. Although the results of the number of personnel have been determined is optimal, in practice, the adjustment needs to be done.

The addition of personnel may not necessarily be the best step is so that the workload can be accepted, but the condition adjustment needs to be done in each position. In addition to addressing the excess workload study conducted 
back towards the tasks performed by each term per section/work unit. The study of the later, the conclusion may be taken whether the need for the addition or reduction of personnel to assist in the tasks of each section or Office per simply done assignment job description of one term per section, to a position on the part of other work units. It can be done so that future work done by the holder of the Office could do with more optimization.

Then it can be seen from a comparison of the number of Optimal Personnel with Personnel according to the List of Personnel Arrangements in table 9.

Table 9. Comparison of the Number of Personnel

\begin{tabular}{|c|c|c|c|c|c|c|c|}
\hline Ma. & $\begin{array}{l}\text { Work Units of } \\
\text { Each Part }\end{array}$ & Positions in Parts & & $\begin{array}{l}\text { Cotin: } \\
\text { ber of } \\
\text { onnel } \\
\text { senl }\end{array}$ & & 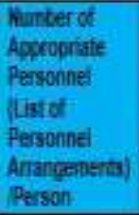 & Conchusion \\
\hline \multirow[t]{2}{*}{1} & \multirow{2}{*}{$\begin{array}{l}\text { Adninistrative } \\
\text { Work }\end{array}$} & $\begin{array}{l}\text { Head of } \\
\text { Adninistrative Affairs }\end{array}$ & 1 & \multirow{2}{*}{\multicolumn{2}{|c|}{3}} & \multirow[t]{2}{*}{11} & \multirow{2}{*}{$\begin{array}{l}\text { Reduction } \\
\text { of } 8 \\
\text { personnel }\end{array}$} \\
\hline & & Staff & 2 & & & & \\
\hline \multirow{6}{*}{2} & \multirow{6}{*}{$\begin{array}{l}\text { Sub Service } \\
\text { Budgat Cost }\end{array}$} & $\begin{array}{l}\text { Head of Sub } \\
\text { Department Budget } \\
\text { And Finance }\end{array}$ & 1 & \multirow{6}{*}{3} & \multirow{6}{*}{13} & \multirow{6}{*}{10} & \multirow{6}{*}{$\begin{array}{l}3 \\
\text { addifional } \\
\text { personnel } \\
\text { were } \\
\text { added }\end{array}$} \\
\hline & & Staff & 4 & & & & \\
\hline & & $\begin{array}{l}\text { Head Of Budget And } \\
\text { Finance Section }\end{array}$ & 1 & & & & \\
\hline & & Staff & 4 & & & & \\
\hline & & $\begin{array}{l}\text { Head Of } \\
\text { Adninistration } \\
\text { Budget And Finance } \\
\text { Section }\end{array}$ & 1 & & & & \\
\hline & & Staff & 2 & & & & \\
\hline \multirow{6}{*}{3} & \multirow{6}{*}{$\begin{array}{l}\text { Accounting } \\
\text { Service Sub }\end{array}$} & $\begin{array}{l}\text { Head Of Sub } \\
\text { Department } \\
\text { Accounting }\end{array}$ & 1 & \multirow[b]{2}{*}{5} & \multirow{6}{*}{11} & \multirow{6}{*}{11} & \multirow{6}{*}{$\begin{array}{l}\text { No need to } \\
\text { add and } \\
\text { reduce } \\
\text { personnel }\end{array}$} \\
\hline & & Staff & 4 & & & & \\
\hline & & $\begin{array}{l}\text { Head Of Section } \\
\text { Adninistrative } \\
\text { Accounting }\end{array}$ & 1 & \multirow{4}{*}{3} & & & \\
\hline & & Staff & 2 & & & & \\
\hline & & $\begin{array}{l}\text { Head of Section Of } \\
\text { The Financial Report }\end{array}$ & 1 & & & & \\
\hline & & Staff & 2 & & & & \\
\hline \multirow{7}{*}{4} & \multirow{2}{*}{ Sub } & $\begin{array}{l}\text { Head Of Sub } \\
\text { Department Finance } \\
\text { Administration }\end{array}$ & 1 & \multirow[b]{2}{*}{2} & \multirow[b]{6}{*}{4} & \multirow{7}{*}{8} & \multirow{4}{*}{ Reduction } \\
\hline & & Staff & 1 & & & & \\
\hline & \multirow[t]{2}{*}{ Department } & $\begin{array}{l}\text { Head of Section } \\
\text { Payment and income }\end{array}$ & 1 & \multirow[b]{2}{*}{1} & & & \\
\hline & & Staff & - & & & & \\
\hline & \multirow{3}{*}{$\begin{array}{l}\text { Finance } \\
\text { Adninistration }\end{array}$} & $\begin{array}{l}\text { Head Of Section of } \\
\text { Financial and }\end{array}$ & & \multirow[b]{3}{*}{1} & & & \multirow{3}{*}{$\begin{array}{l}\text { of } 2 \\
\text { personnel }\end{array}$} \\
\hline & & $\begin{array}{l}\text { Personnel Dats } \\
\text { System Cosching }\end{array}$ & 1 & & & & \\
\hline & & Staff & - & & & & \\
\hline
\end{tabular}

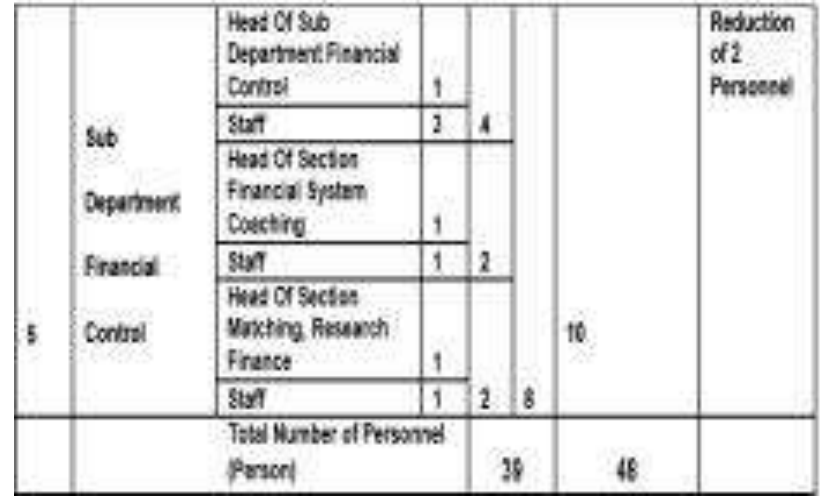

The optimal number of personnel calculation results has been done in this study have different results with the condition number of a corresponding list of personnel arrangement at this time. On the number of personnel in each section/work unit, if it turns out an appropriate List of Personnel Arrangements more than the optimal amount of calculation appropriate, so it must be reduced by the number of casualties.

Vice versa when in the List of Personnel Arrangements than the calculation result must be added than lost. Therefore, it should be done with the determination of criteria, which can then serve as a benchmark assessment of appropriate workload units. Suppose the work units have low workloads that can do the deletion or merge with other work units. Adjustment of the number of personnel is conducted to further equally the workload of each part of the work unit to be more optimal.

\section{DISCUSSION}

The workload in the Accounting Institutions indicates an excess and shortage of workloads are received by each section/unit of work. In accordance with the calculation with the mental workload approach, namely the NASA-TLX, known to be the largest mental workload experienced by the Head of Section Payment and Income with an average value of WWL 79.33. Whereas the calculation of the appropriate approach to the 
burden of the task per position physically, obtained the results that the Head of Sub Department Budget and Finance has a total time of completion of the tasks of the highest officials of the other structures, that is about 1860 seconds so there has to be the addition of a number of assistants. Comparison of the calculation of the result of workload mental with the physical. Obtained that mental workload on all structural officials at

Accounting InstitutionsException Head of Administrative Affairs has the greatest burden that is the value 3 with high category. While the physical workload, Head of Sub Department of Budget and Finance, the Head of the Budget and Finance Section and the Head of Sub Department Accounting represents the largest load value, that is 4 or category is very high. So that it can be drawn to the conclusion that the physical workload is more dominant than the mental workload that occurs at each structural level officials in the Eastern Fleet Finance Offices.

\section{CONCLUSION.}

The optimal number of personnel in each section/work units in accordance with the physical workload is based on the Regulation of the Minister of State Apparatus Empowerment, that is part of the Administrative Work needed 3 people personnel, Sub Service Budget Cost 13 people personnel, Accounting Service Sub 11 personnel, Sub Department Finance Administration personnel and four Sub Department Financial Control 8 personnel. So for a whole number of optimal personnel required level Sub Department down is 39 people personnel.

\section{ACKNOWLEDGEMENT.}

This paper has been supported by The Indonesia Naval Technology College (a high school Technology Navy/STTAL).

\section{BIBLIOGRAPHY}

Barnes, r.m. (1980) Motion and Time Study: Design and Measurement of Work, New York: John Wiley \& Sons.

Ben, D.S. (2014) 'Cyber Vigilance: Effect of Signal Probability and Event Rate', Human Factors and Ergonomics Society 58th Annual Meeting, pp. 1771-1775.

Bhandary, s.p. (2016) 'NASA Task Load Index Scale to Evaluate the Cognitive film on Workload during Cardiac Anesthesia Based', International Journal of Anesthesiology \& Research (IJAR), pp. 300-304.

Carrie, W. (2017) 'Maximizing Efficiency and Reducing Robotic Surgery Costs Using the NASA Task Load', AORN Journal, pp. 284-290.

Chang, S.Y. and Chen, T.H. (2006) 'Discriminating Relative Workload Level by Data Envelopment Analysis', Industrial Ergonomics.

Ghanbary, S.m.a. (n.d) 'Evaluation of Rating Scale Mental Effort (RSME) effectiveness for the mental film on workload assessment in nurses.', Isfahan University of Medical Sciences, Isfahan, Iran.

Gloria, Y.b.z. (2008) 'Assessment of film on Workload Using NASA Task Load Index in Perianesthesia Nursing', Journal of Perianesthesia Nursing, pp. 102-110.

Gustomo, r.h. (2013) 'Film on workload Analysis for Planning Needs of Employees in The Corporate Administration Unit PT TIMAH (Persero) TBK', The Indonesian Journal of Business Administration, vol. 2, pp. 2290-2297. 
Hart, S.G. and Staveland, L.E. (1988) 'Development of NASA-TLX (Task Load Index): Results of Emprical and Theoretical Research.', Advances in Psychology, pp. 139-183.

Marc, M.A. (2013) 'Fuzzy-TLX: using fuzzy integrals for evaluating human mental film on workload with NASA-Task Load. ', Ergonomics, vol. 56, pp. 752-763.

Mohsen, M.a.m. (2015) 'Evaluation of Mental Ward's Workload among ICU Nurses', Health Promotion Perspectives, pp. 280-287.

Niebel, b.f. (2002) Methods, Standards and Work Design, $7^{\text {th }}$ edition, New York: John Form Wiley \& Sons.
Seker, a. (2014) 'Using Outputs of the NASA-TLX for Building a mentally', Gazy University Journal of Science, pp. 1131-1142.

Shiow-Yun Chang, t.h.c. (2006) 'Discriminating film on workload relative level by data envelopment analysis', International Journal of Industrial Ergonomics, pp. 773-778.

Young, G. and Zavelina, L. (2008) 'Assesment of Workload Using NASA Task Load Index in Perianesthesia Nursing', Journal of Perianesthesia Nursing, vol. 23, no. 2, pp. 102-110. 